\title{
Analysis of Mercury Levels in Agricultural Soils and Citrus Varieties from Benue State, Nigeria
}

\author{
Shaapera Ugbidye*, Ishaq Shaibu Eneji, Raymond Wuana, Rufus Sha' Ato \\ Department of Chemistry, Federal University of Agriculture, Makurdi, Nigeria \\ Email address: \\ shaapmandoo@gmail (S. Ugbidye) \\ ${ }^{*}$ Corresponding author \\ To cite this article: \\ Shaapera Ugbidye, Ishaq Shaibu Eneji, Raymond Wuana, Rufus Sha' Ato. Analysis of Mercury Levels in Agricultural Soils and Citrus \\ Varieties from Benue State, Nigeria. Science Journal of Analytical Chemistry. Vol. 8, No. 2, 2020, pp. 65-71. \\ doi: $10.11648 /$ j.sjac.20200802.15
}

Received: December 17, 2019; Accepted: February 3, 2020; Published: May 28, 2020

\begin{abstract}
Mercury levels in agricultural soils and three citrus varieties (Washington, Ibadan Sweet and Valencia) in seven (7) local government areas of Benue State were determined using standard techniques. The mean physico-chemical parameters of the soils ranges from: $\mathrm{pH}(5.20-6.10)$; $\mathrm{CEC}\left(10.5-12.9 \mathrm{cmolkg}^{-1}\right)$; organic carbon $(2.35-3.39 \%)$ and organic matter $(6.17-7.37 \%)$. The mean $\mathrm{Hg}$ levels in the soils ranges from $20.5-21.2 \mu \mathrm{gkg}^{-1}$. The mean proximate parameters are: fat in Valencia (0.330\%); fibre in Valencia (0.490\%); moisture in Valencia (87.4\%); ash in Valencia $(1.80 \%)$ and carbohydrate in Ibadan sweet (17.7\%). The mean $\mathrm{Hg}$ concentration in the citrus juice ranges from: Washington $\left(0.770-6.35 \mu \mathrm{gkg}^{-1}\right)$; Ibadan sweet $\left(0.770-6.53 \mu \mathrm{gkg}^{-1}\right)$ and in Valencia $\left(0.770-5.22 \mu \mathrm{gkg}^{-1}\right)$. The order of accumulation of $\mathrm{Hg}$ in the citrus varieties is Ibadan sweet $>$ Washington $>$ Valencia. The concentrations of $\mathrm{Hg}$ in the three citrus fruit juice and soil do not exceed the WHO/FAO permissible limits of 100 and $1000 \mu \mathrm{gkg}^{-1}$ for foods and agricultural soils respectively. However, continues monitoring is hereby recommended.
\end{abstract}

Keywords: Agricultural Soil, Washington, Ibadan Sweet, Valencia, CV-AAS

\section{Introduction}

The need for Nigeria to key into minamata convention on mercury in line with United Nations Environmental Programme precipitated the motive of this research. Orange (Citrus sinensis) fruits play an essential role in human nutrition as they are good sources of antioxidants such as ascorbic acid, carotenoids; tocophenol and phenolic compounds [1]. It also contains some other nutrients such as proteins, carbohydrate, fibre and minerals. Vitamin $\mathrm{C}$ (ascorbic acid) is the most dominant nutrient in orange fruits, it is essential for the synthesis of collagen and its deficiency leads to scurvy which causes loss of teeth [2]. Globally, Nigeria ranks 9 th position among the world top 10 producers of citrus sinensis with Benue state giving the highest annual production of the commodity [3]. Oranges are very important protective foods and useful for the maintenance of good health, prevention and treatment of various diseases [4]. Frequent consumption of fruit is associated with reduced risk of cancer, cardiovascular diseases, stroke, Alzheimer disease, cataracts, and some of the functional declines associated with aging [5]. The large input of mercury $(\mathrm{Hg})$ into the arable lands has resulted in the widespread occurrence of mercury contamination in the entire food chain. $\mathrm{Hg}$ is a unique metal due to its existence in different forms e.g., $\mathrm{HgS}, \mathrm{Hg}^{2+}, \mathrm{Hg}^{0}$ and methyl-Hg. However, in agricultural soil, ionic form $\left(\mathrm{Hg}^{2+}\right)$ is predominant [6]. The persistence nature of heavy metals in the environment and subsequent accumulation in fruits is discouraging the intake of this commodity [7]. Dietary exposure to mercury has been identified as a risk to human health through the consumption of vegetable crops [8]. Food safety is important for the survival of all living organisms involved in the food chain. In most developing countries like Nigeria, the quest for rapid economic growth through industrialization and modern agriculture have resulted in a concomitant inflow of several contaminants like heavy metals into the environment [9]. Despite the benefits of fruit consumption on human health, heavy metal contents in fruits can be toxic when they exceed the recommended health levels or when they bio-accumulate in the body over a long period [10]. This study aims at determining the level of mercury in three orange fruits juice (Washington, Ibadan 
sweet and Valencia), soil and some physico-chemical properties of the soil.

\section{Materials and Methods}

\subsection{Sample Collection}

Benue State lies within the lower River Benue trough in the middle belt region of Nigeria with Landmass of 34,059 square kilometers and a population of 4,253,641 in 2006 census. Agriculture is the mainstay of the economy engaging over $75 \%$ of the working population and its geographic coordinates are longitude $7^{\circ} 47^{\prime}$ and $10^{\circ} 0^{\prime}$ East, Latitude $6^{\circ}$ $25^{\prime}$ and $8^{\circ} 8^{\prime}$ North and it is characterized by an annual rainfall of $1250-1500 \mathrm{~mm}$. Orange (citrus) and soil samples were collected from seven (7) Local Government Areas between January - April, 2018, because of the dominance in orange production. Orange farms were located from three (3) council wards of each Local Government where the citrus sinensis (sweet orange) fruits (Washington, Ibandan Sweet and Valencia) samples were plugged into a polyethene container hanged on a stick and bulked based on varieties, placed into appropriately labeled sacks and transported to the Departments of Crop Production and Biology, Federal University of Agriculture Makurdi, where the plant parts (orange fruits) were taxonomically identified and authenticated by professionals, also, the soil samples were taken using auger at the depth of $0-20 \mathrm{~cm}$ after which the samples were conveyed to the laboratory of Chemistry Department Federal University of Agriculture Makurdi for storage and pretreatment.

\subsection{Sample Preparation and Digestion}

The orange fruits were washed with tap water and then with distilled water after which the juice was squeezed manually into separate beakers. About $200 \mathrm{~mL}$ of juice was obtained from each sample. The juice was filtered, mixed well and exactly $1.0 \mathrm{~g}$ of the homogenized orange sample was weighed into $100 \mathrm{~mL}$ volumetric digestion flask and a mixture of $2 \mathrm{~mL} \mathrm{H}_{2} \mathrm{O}, 4 \mathrm{~mL} \mathrm{HNO}_{3}-\mathrm{HClO}_{4}(1: 1)$ and $10 \mathrm{~mL}$ $\mathrm{H}_{2} \mathrm{SO}_{4}$ were added. The mixture was then heated at a temperature between 150 and $250^{\circ} \mathrm{C}$ until the solution was clear. The sample solution was then cooled and diluted to 100 $\mathrm{mL}$ with distilled water. Also, exactly $1.0 \mathrm{~g}$ of the homogenized soil sample was weighed into $100 \mathrm{~mL}$ volumetric digestion flask and the same digestion procedure applied. A blank and standard solution digests using $\mathrm{Hg}$ solutions were subjected to the same treatment and the contents analyzed for mercury using cold vapour atomic absorption spectrophotometer [11].

\section{Results}

Table 1. Physico-chemical Parameters of the Soil.

\begin{tabular}{lllll}
\hline Local Government Areas & pHin 0.01 M CaCl & pH in Distilled Water & Sand\% & Silt\% \\
\hline Kastina-Ala & $5.50 \pm 0.3$ & $7.10 \pm 0.4$ & $76.0 \pm 3$. & $8.23 \pm 0.1$ \\
Konshisha & $5.20 \pm 0.4$ & $6.10 \pm 0.2$ & $76.1 \pm 5$ & $7.70 \pm 0.6$ \\
Kwande & $6.10 \pm 0.2$ & $6.70 \pm 0.3$ & $77.0 \pm 3$ & $16.2 \pm 5$ \\
Logo & $5.70 \pm 0.4$ & $6.90 \pm 0.3$ & $73.7 \pm 0.1$ & $15 \pm 0.8$ \\
Ukum & $5.70 \pm 1$ & $6.40 \pm 0.3$ & $81.2 \pm 0.1$ & $7.14 \pm 0.1$ \\
Ushongo & $5.70 \pm 0.4$ & $6.40 \pm 0.3$ & $77.0 \pm 5$ & $18.1 \pm 1$ \\
Vandeikya & $6.10 \pm 0.2$ & $6.70 \pm 0.5$ & $72.2 \pm 3$ & $11.0 \pm 0.1$ \\
\hline
\end{tabular}

Table 2. CEC, Organic Carbon and Organic Matter of the Soil.

\begin{tabular}{llll}
\hline Local Government Areas & CEC $\left.(\mathbf{c m o l k g})^{-1}\right)$ & Organic Carbon\% & Organic Matter\% \\
\hline Kastina-Ala & $11.48 \pm 1$ & $2.94 \pm 1$ & $7.35 \pm 2$ \\
Konshisha & $10.53 \pm 2$ & $2.89 \pm 0.3$ & $7.37 \pm 1$ \\
Kwande & $12.86 \pm 1$ & $2.53 \pm 1$ & $6.42 \pm 2$ \\
Logo & $12.10 \pm 0.2$ & $3.21 . \pm 1$ & $6.17 \pm 2$ \\
Ukum & $11.23 \pm 1$ & $2.35 \pm 1$ & $6.63 \pm 0.3$ \\
Ushongo & $12.45 \pm 1$ & $3.39 \pm 1$ & $6.90 \pm 1$ \\
Vandeikya & $11.91 \pm 1$ & $3.30 \pm 0.1$ & $7.08 \pm 1$ \\
\hline
\end{tabular}

Table 3. Fat and Fibre Contents of the Citrus Varieties.

\begin{tabular}{|c|c|c|c|c|c|c|}
\hline \multirow{2}{*}{ Local Government Areas } & \multicolumn{3}{|c|}{ Fat\% } & \multicolumn{3}{|c|}{ Fibre \% } \\
\hline & Washington & Ibadan Sweet & Valencia & Washington & Ibadan Sweet & Valencia \\
\hline Katsina-Ala & $0.260 \pm 0.1$ & $0.330 \pm 0.1$ & $0.330 \pm 0.1$ & $0.230 \pm 0.02$ & $0.240 \pm 0.04$ & $0.220 \pm 0.02$ \\
\hline Konshisha & $0.220 \pm 0.01$ & $0.230 \pm 0.02$ & $0.220 \pm 0.02$ & $0.350 \pm 0.1$ & $0.300 \pm 0.04$ & $0.390 \pm 0.02$ \\
\hline Kwande & $0.210 \pm 0.01$ & $0.260 \pm 0.1$ & $0.270 \pm 0.01$ & $0.410 \pm 0.00$ & $0.390 \pm 0.1$ & $0.420 \pm 0.1$ \\
\hline Logo & $0.200 \pm 0.01$ & $0.230 \pm 0.02$ & $0.190 \pm 0.03$ & $0.220 \pm 0.01$ & $0.310 \pm 0.1$ & $0.220 \pm 0.1$ \\
\hline Ukum & - & $0.210 \pm 0.02$ & $0.210 \pm 0.03$ & - & $0.250 \pm 0.1$ & $0.200 \pm 0.02$ \\
\hline Ushongo & $0.310 \pm 0.03$ & $0.250 \pm 0.02$ & $0.310 \pm 0.1$ & $0.400 \pm 0.01$ & $0.370 \pm 0.01$ & $0.490 \pm 0.1$ \\
\hline Vandeikya & $0.270 \pm 0.1$ & $0.240 \pm 0.04$ & $0.250 \pm 0.03$ & $0.220 \pm 0.02$ & $0.230 \pm 0.01$ & $0.300 \pm 0.04$ \\
\hline
\end{tabular}


Table 4. Moisture and Ash Contents of the Citrus Varieties.

\begin{tabular}{llllll}
\hline \multirow{2}{*}{ Local Government Areas } & \multicolumn{3}{c}{ Moisture\% } \\
\cline { 2 - 6 } & Washington & Ibadan Sweet & Valencia & Washington & Ibadan Sweet \\
\hline Katsina-Ala & $82.8 \pm 1$ & $81.6 \pm 2$ & $82.0 \pm 2$ & $1.60 \pm 0.2$ & $1.40 \pm 0.2$ \\
Konshisha & $79.4 \pm 1$ & $80.7 \pm 2$ & $81.2 \pm 1$ & $1.50 \pm 1$ & $1.10 \pm 0.2$ \\
Kwande & $83.1 \pm 0.0$ & $83.6 \pm 3$ & $82.6 \pm 1$ & $2.10 \pm 0.0$ & $1.40 \pm 0.2$ \\
Logo & $81.4 \pm 1.0$ & $80.2 \pm 1$ & $81.4 \pm 2$ & $1.70 \pm 1$ & $1.40 \pm 0.2$ \\
Ukum & - & $79.5 \pm 1$ & $80.4 \pm 0.3$ & - & $1.40 \pm 0.2$ \\
Ushongo & $86.2 \pm 2$ & $86.9 \pm 3$ & $87.4 \pm 2$ & $1.20 \pm 0.3$ & $1.30 \pm 0.1$ \\
Vandeikya & $81.6 \pm 1$ & $79.5 \pm 1$ & $80.9 \pm 1$ & $1.60 \pm 0.3$ & $1.30 \pm 0.3$ \\
\hline
\end{tabular}

Table 5. Protein and Carbohydrate Contents of the Citrus Varieties.

\begin{tabular}{|c|c|c|c|c|c|c|}
\hline \multirow{2}{*}{ Local Government Areas } & \multicolumn{3}{|c|}{ Protein \% } & \multicolumn{3}{|c|}{ Carbohydrate\% } \\
\hline & Washington & Ibadan Sweet & Valencia & Washington & Ibadan Sweet & Valencia \\
\hline Katsina-Ala & $0.82 \pm 0.1$ & $0.79 \pm 0.1$ & $0.74 \pm 0.1$ & $14.3 \pm 1$ & $15.7 \pm 3$ & $15.0 \pm 2$ \\
\hline Konshisha & $0.74 \pm 0.1$ & $0.84 \pm 0.1$ & $0.89 \pm 0.1$ & $17.3 \pm 1$ & $15.2 \pm 1$ & $15.9 \pm 1$ \\
\hline Kwande & $0.63 \pm 0.01$ & $0.76 \pm 0.1$ & $0.71 \pm 0.1$ & $13.5 \pm 0.02$ & $13.6 \pm 3$ & $14.8 \pm 1$ \\
\hline Logo & $0.86 \pm 0.1$ & $0.76 \pm 0.1$ & $0.77 \pm 0.04$ & $15.7 \pm 0.2$ & $16.8 \pm 1$ & $15.7 \pm 2$ \\
\hline Ukum & - & $0.80 \pm 0.1$ & $0.76 \pm 0.1$ & - & $16.0 \pm 1$ & $15.9 \pm 1$ \\
\hline Ushongo & $0.66 \pm 0.1$ & $0.73 \pm 0.1$ & $0.62 \pm 0.1$ & $11.1 \pm 3$ & $10.2 \pm 3$ & $9.39 \pm 2$ \\
\hline
\end{tabular}

Table 6. Concentration of Hg with Standard Deviations in Citrus Varieties and Soil.

\begin{tabular}{llll}
\hline Local Government Areas & Washington $\left(\boldsymbol{\mu g k g}{ }^{-1}\right)$ & Ibadan Sweet $\left(\boldsymbol{\mu g k g} \mathbf{g}^{-1}\right)$ & Valencia $\left(\boldsymbol{\mu g k g}^{-1}\right)$ \\
\hline Kastina-Ala & $6.35 \pm 2$ & $6.53 \pm 1$ & $5.22 \pm 1$ \\
Konshisha & $0.770 \pm 0.0$ & $0.770 \pm 0.0$ & $0.770 \pm 0.0$ \\
Kwande & $2.20 \pm 0.0$ & $2.30 \pm 0.3$ & $0.770 \pm 0.0$ \\
Logo & $2.88 \pm 1$ & $1.84 \pm 1$ & $3.38 \pm 1$ \\
Ukum & - & $3.92 \pm 1$ & $0.770 \pm 0.0$ \\
Ushongo & $0.770 \pm 0.0$ & $0.578 \pm 0.3$ & $0.770 \pm 0.0$ \\
Vandeikya & $2.13 \pm 1$ & $1.80 \pm 2$ & $1.71 \pm 1$ \\
\hline
\end{tabular}

\section{Discussion}

In this work, a total of 161 parameters ( $\mathrm{pH}$, sand, silt, clay, organic carbon, CEC, organic matter and mercury) were examined in the studied area.

\subsection{Physico-Chemical Parameters of the Soil}

\subsection{1. $\mathrm{pH}$}

Table 1 shows the $\mathrm{pH}$ of the agricultural soils in $0.01 \mathrm{M}$ $\mathrm{CaCl}_{2}$ solution and distilled water in the range of $5.20-6.10$ and $6.10-7.10$, respectively. The lowest $\mathrm{pH}$ value was recorded in Konshisha and the highest in Kwande and Vandeikya in $0.01 \mathrm{M} \mathrm{CaCl}{ }_{2}$. This may be due to the ionization of more hydrogen ions in the soil solution of Konshisha than that of Kwande and Vandeikya. Similarly, the mean $\mathrm{pH}$ value in Ukum and Ushongo are low and the highest value is recorded in Katsina-Ala in distilled water, probably due to the same reason. The $\mathrm{pH}$ range of $4.56-$ 7.71 in roadside soil from Wurukum, Gboko road, Federal lowcost and Federal medical centre was reported [12]. The $\mathrm{pH}$ of agricultural soils in selected farms in Abraka, Delta State revealed a $\mathrm{pH}$ range of $4.20-5.45$ [13]. The low $\mathrm{pH}$ of some orange farmland soils may be attributable to the presence of hydrogen cyanide from the perennial crops [14]. It may also be attributed to the high rainfall common in some of those areas which could leach out basic cations from the farmland soils [13].

\subsubsection{Sand}

The result of the soil particles is presented in Table 1; the mean particle size is in the range of $72.2-81.2 \%$. The lowest value was recorded in Vandeikya and the highest value in Ushongo. A preliminary assessment of top soils around Wurukum Abattoir in Makurdi Benue State, Nigeria revealed the particle size distribution in sand soil to be in the range of $23-62 \%$ [15]. The sand particles in soils around mechanic workshops in Makurdi were reported in the range of $73.4-$ $83.3 \%$ [16]. The assessment of the physicochemical properties of soil around Benue Cement Company revealed sand particle size in the range of $70.70-74.70 \%$ [17].

\subsubsection{Silt}

The mean silt particles are in the range of $7.18-8.52 \%$ as shown in Table 1. The lowest value was recorded in Kwande and the highest value in Ushongo. The analysis of irrigation water in river Katsina - Ala reported silt in the range of 17.0 $-20.0 \%$ [18]. Silt content in the range of $10.70-17.70 \%$ in soils around Benue Cement Company was reported [17]. The investigation of soils in mechanic workshops in Makurdi revealed a silt range of $8.5-23.1 \%$ [16]. The preliminary assessment of top soils in Wurukum abattoir reported silt content in the range of $17-23 \%$ [15]. The literature values reported when compared are more than the value recorded in this work and could be as a result of the engine oil used 
which makes the soil compact.

\subsubsection{Clay}

The mean result ranges from $11.0-19.9 \%$ with the lowest value recorded in Ukum and the highest value in Vandeikya as represented in Table 1. The clay content of soil in the range of $10.2-16.6 \%$ was reported [17]. The clay content of top soil in Wurukum revealed a range of $21-57 \%$ [15] which is higher than the values recorded in this work. The clay content of soil was also reported in the range of $8.0-15 \%$ [18]. The clay contents of surrounding soils in ceramic and Pharmaceutical industrial areas gave a range of $7.6-13.2 \%$ and $8.40-11.6 \%$ respectively [19].

\subsubsection{Cation Exchange Capacitiy}

The mean result of CEC ranges from $10.5-12.9 \mathrm{cmolkg}^{-}$ ${ }^{1}$ with the lowest CEC value recorded in Konshisha and the highest in Kwande as presented in Table 2. A study carried out on agricultural farmland soils in Abraka, Delta State, Southern, Nigeria reported Cation Exchange Capacity ranging from 1.04-7.96 $\mathrm{cmolkg}^{-1}$ [13]. A CEC of 13.0 and $91.1 \mathrm{cmolkg}^{-1}$ in dumpsite waste in Yenagoa, Nigeria was reported [20].

\subsubsection{Organic Carbon}

The mean values of organic carbon ranges from 2.35 $3.39 \%$ with the lowest value in Ukum and the highest value in Ushongo as shown in Table 2. The mean value of organic carbon in some selected site in Abeokuta were reported to be $0.02-8.48 \%$ [21] which is higher than the value recorded in work. The organic carbon in roadside soils in Makurdi metropolis in the range of $0.27-5.44 \%$ was reported [12] which is higher than the values recorded in this research. The organic carbon of some agricultural farms were reported in Delta State in the range of $0.95-2.02 \%$ [13] less than the value recorded in this work.

\subsubsection{Organic Matter}

The mean organic matter recorded is in the range of $6.17-$ $7.37 \%$ with the lowest value reported in Logo and the highest in Konshisha as shown in Table 2. The organic matter content of soil in automobile mechanic village in Apir and North bank were investigated and the values reported are in the range of $1.46-2.39 \%$ [22] which is less than the values recorded in this research.

\subsection{Proximate Parameters of the Citrus Varieties}

\subsubsection{Fat Content}

The result of the analysis revealed the levels of fat in the orange varieties in the range of: Washington $(0.200-$ $0.310 \%)$; Ibadan sweet $(0.210-0.330 \%)$ and Valencia $(0.190$ $-0.330 \%$ ). Low level of fat in Washington was recorded in Logo and highest level was observed in Ushongo, in Ibadan sweet, low level of fat was observed in Ukum and the highest in Katsina-Ala and in Valencia, the lowest levels was observed in Logo and the highest levels in Kastina-Ala as presented in Table 3. The fat content of oranges from Benue State and Rivers State were reported to be $0.65 \%$ and $2.0 \%$
[23] which are higher than the values recorded in this work probably due to time of collection of the samples. The fat content of citrus sinensis was reported to be $10.0 \%$ [24] which is by far higher than the values reported in this work. Proximate composition of citrus sinensis in Northern Nigeria reported the fat content of $0.06 \%$ [25] less than the values recorded in this work. The differences in the values of fat recorded in the citrus varieties could be due to species, the trend in the result showed that Valencia $=$ Ibadan sweet $>$ Washington.

\subsubsection{Fibre Content}

The result of the crude fibre of the three citrus varieties analyzed in this work are in the range of Washington $(0.220-$ $0.410 \%)$, Ibadan sweet $(0.230-0.390 \%)$ and Valencia $(0.200$ - $0.490 \%$ ). The lowest fibre content in Washington was recorded in Logo and Vandeikya and the highest in Kwande. In Ibadan sweet, the lowest value was observed in Vandeikya and the highest in Kwande and in Valencia, the lowest values was recorded in Ukum and the highest in Ushongo as shown in Table 3. The fibre content of oranges in Benue State and Rivers State revealed the mean values of $0.18 \pm 0.06 \%$ and $0.41 \pm 0.08 \%$ [23] this values are less compared to the ones recorded in this research and may be as a result of mineral composition and variety. The nutritional potential of citrus sinensis revealed the fibre content value of $13.5 \%$ [26] which is higher than the values obtained here may be as a result of time of sample collection and climate. The fibre content of citrus sinensis in Northern Nigeria was reported to be $2.82 \%$ [25]. The result of the analysis shows the trend in the fibre composition of the citrus varieties in order of Valencia $>$ Washigton $>$ Ibadan sweet.

\subsubsection{Moisture Content}

The moisture content reported in the three orange species ranges from: Washington $(79.4-86.2 \%)$, Ibadan sweet $(79.5$ - $86.9 \%$ ) and Valencia $(80.4-87.4 \%)$. The lowest value of moisture content was observed in Konshisha and the highest in Ushongoin Washington, in Ibadan sweet, the lowest values were observed in Ukum and Vandeikya and the highest in Ushongo, in Valencia, the lowest value is recorded in Ukum and the highest in Ushongo as presented in Table 3. The moisture content of oranges in Benue State and Rivers State were reported to be $88.8 \pm 0.07 \%$ and $88.9 \pm 0.06 \%$ respectively [23], the values are higher than what is reported in this analysis. The moisture content of fresh juice from three citrus species were; sweet orange $(80.5 \%)$, lemon $(85.1 \%)$ and lime $(75.6 \%)$ [27], which is within the range of the result of this analysis. The moisture content of citrus sinensis was reported to be $9.78 \%$ [26] which is far less than the values recorded in this work and other similar research works and this could be due to differences in species and season. The trend of the moisture content in the citrus varieties follows Valencia $>$ Ibadan sweet $>$ Washigton.

\subsubsection{Ash Content}

The result of this analysis revealed that the ash content of the three citrus varieties are in the range of Washington (1.20 
$-1.70 \%)$, Ibadan sweet $(1.10-1.50 \%)$ and Valencia $(1.30-$ $1.80 \%$ ). The lowest value was recorded in Ushongo and the highest in Logo in Washington, in Ibadan sweet, the lowest value is recorded in Konshisha and the highest value in Ushongo and in Valencia, the lowest value is recorded in Kwande and the highest value is reported in Katsina-Ala as shown in Table 4. The ash content of oranges in Benue State and Rivers State were reported to be $0.630 \%$ and $0.490 \%$ respectively [23]. The ash content of citrus sinensis in Northern Nigeria was reported to be $0.62 \%$. [25]. The proximate composition of fresh juice from three citrus species recorded the ash contents in sweet orange $(0.60 \%)$, lemon $(0.50 \%)$ and lime $(0.15 \%)$ [27], these values reported by these researchers are less than the values recorded in this work and may be due to species. The trend of the ash content in the citrus varieties are Valencia $>$ Washington $>$ Ibadan sweet.

\subsubsection{Protein Content}

The result of proteins analyzed revealed the protein content of the three orange varieties to be in the range of $(0.63-0.86 \%)$ Washington, $(0.73-0.84 \%)$ Ibadan sweet and $(0.62-0.89 \%)$ Valencia. The lowest value in Washington was observed in Kwande, the highest in Logo, in Ibadan sweet, the lowest value is in Ushongo, the highest in Konshisha and in Valencia, the lowest value is recorded in Ushongo and the highest in Konshisha as presented in Table 5. The protein contents of oranges from Benue and Rivers States were investigated, the mean values are; $0.44 \pm 0.06 \%$ and $0.44 \pm 0.07 \%$ [23]. The protein content of orange leave was reported in the range of $3.80-3.65 \%$ [28], which is high compared to the value obtained in this analysis and this could be due to the fact that the leaves are the organs for photosynthesis in the plant and may store sufficient carbohydrates temporarily. The protein content of orange juice was also reported, the mean value is $0.74 \pm 0.03 \%$ [23], which is less than the value reported in this analysis. The trend is Valencia > Washington > Ibadan sweet.

\subsubsection{Carbohydrate Content}

The carbohydrate content of three orange varieties gave a range of $11.1-17.3 \%$ in Washington, $10.2-17.7 \%$ in Ibadan sweet and $9.39-16.4 \%$ in Valencia. The lowest carbohydrate content was observed in Ushongo and the highest values were recorded in Konshisha in Washington. In Ibadan sweet, the lowest value was in Ushongo and the highest in Vandeikya also in Valencia, the lowest value was in Ushongo and the highest value in Vandeikya as shown in Table 5. The carbohydrate content of oranges from Benue State and Rivers State were reported to be $9.30 \%$ and $7.71 \%$ respectively [23] which are less than the values reported in this analysis. The carbohydrate content of citrus sinensis in Nigeria was reported to be $18.6 \%$ [29] which is in agreement with the values recorded in this research. The carbohydrate content of citrus sinensis was reported to be $42.9 \%$ [24] higher than the values recorded in this work. The low value of carbohydrate could be due to the unprocessed nature of the fruits.
Processed fruits are expected to have higher values of carbohydrates, also species type. The trend of carbohydrate content in this analysis is Ibadan sweet $>$ Washington $>$ Valencia.

\subsection{Hg in Orange Juice and Soil}

The result as represented in Table 6 showed the range of $\mathrm{Hg}$ in the citrus varieties and soil as: Washington $(0.770-$ $\left.6.35 \mu \mathrm{gkg}^{-1}\right)$, Ibadan sweet $\left(0.770-6.53 \mu \mathrm{gkg}^{-1}\right)$, Valencia $\left(0.770-5.22 \mu \mathrm{gkg}^{-1}\right)$ and soil $\left(20.5-21.2 \mu \mathrm{gkg}^{-1}\right)$. The levels of $\mathrm{Hg}$ in Ukum in Washington were below detection limits. High levels of $\mathrm{Hg}$ were observed in in Katsina-Ala in Washington $\left(6.35 \mu \mathrm{gkg}^{-1}\right)$, Ibadan sweet $\left(6.53 \mu \mathrm{gkg}^{-1}\right)$ and Valencia $\left(5.22 \mu \mathrm{gkg}^{-1}\right)$. $\mathrm{Hg}$ values reported in soils are $2410 \mu \mathrm{gkg}^{-1}$ which is higher than the values reported in this work [30]. The levels of $\mathrm{Hg}$ in soils of Anka area were recorded in the range of $2153-12924 \mu \mathrm{gkg}^{-1}$ which is higher than the values in this research [31]. The levels of $\mathrm{Hg}$ in industrial soils in Kaduna State were recorded to be $28800 \mu \mathrm{gkg}^{-1}$ which is higher than the values reported in this research [32]. The levels of $\mathrm{Hg}$ distribution in polluted soils in the range of $220-1880 \mu \mathrm{gkg}^{-1}$ were recorded which are higher than the values reported in this research [33]. The trend of $\mathrm{Hg}$ accumulation in the orange species is Ibadan sweet $>$ Washington $>$ Valencia. The accumulation may be due to orange type, solubility in soil, age, and volume of agrochemicals and the use of substances containing mercury (soaps, creams and batteries). The results of all the samples analyzed for $\mathrm{Hg}$ are below WHO/FAO (100 $\mu \mathrm{gkg}-1)$ limits for $\mathrm{Hg}$ in foods. Also, the level of $\mathrm{Hg}$ analyzed in this research in all the soils is below WHO/FAO $\left(1000 \mu \mathrm{gkg}^{-1}\right)$ limits in agricultural soils.

\section{Conclusion}

The result of the analysis show that the level of $\mathrm{Hg}$ in the different orange fruits and soil analyzed do not exceeded the prescribed WHO and FAO maximum permissible limit. $\mathrm{Hg}$ accumulation may lead to acute toxicity; metals enter into the food chain through polluted environment. The concentration of $\mathrm{Hg}$ in the orange varieties is in the order of Washington $>$ Ibadan sweet $>$ Valencia. Further studies should be carried out on other fruits since there is the probability of metal transfer from soil to fruits.

\section{References}

[1] Morand, C., Claude, D., Dragan, M., Delphine, L., Jean F. M. and Augustin, S. (2011): Herperidins contributes to the vascular protective effect of orange juice, a randomized crossover study in healthy volunteers. American Journal of Clinical Nutrition, 93: 73-80.

[2] Baturh, Y. and Olutola, O. (2016). A Study of the Nutritional Composition of Freshly Squeezed and Processed Orange Juice. Food Science and Quality Management, 48: 126-132. 
[3] Ortese, E., Baiyeri, K. P. and Ugese, F. D. (2012). Demographic Features of Citrus Producers and gronomic Management of the Crop in Benue State, Nigeria. PAT, 8: 180190.

[4] D’Mello, J. P. F. (2003). Food safety. In Contamination and Toxins. CABI Publishing, Willingford, Oxon, UK, Cambridge pp. $480-482$.

[5] Liu, R. H. (2003). Health benefits of fruit and vegetables are from additive and synergistic combinations of phytochemicals. American Society of Clinical Nutrition, 78: $517 \mathrm{~S}-520 \mathrm{~S}$

[6] Han, F. X., Su, Y., Mont, D. L., Waggoner, A. C. and Plodine, J. M. (2006). Binding distribution and plant uptake of mercury in a soil from Oak Ridge, Tennesse, USA. Science Total Environment, 368: 753-768.

[7] Sharma, R. K., Agarwal, M. and Marshall, F. (2007). Heavy metals Contamination of soil \& vegetable in suburban areas of Varanasi, India. Ecotoxicology and Environmental Safety. 66: $258-266$.

[8] Kachenko, A. G. and Singh, B. (2006). Heavy metals contamination in vegetables grown in urban and metal smelter contaminated sites in Australia. Water, Air and Soil Pollution 169: 101-123.

[9] Otitoloju, A. A. (2016). Today's Apple: perspective of an EnvironmentalToxicologist. 12th Inaugural Lecture, University of Lagos. University of Lagos Press. 1-77pp.

[10] Orisakwe, O. E., Nduka, J. K., Amadi, C. N. Dike, D. O and Bede, O. (2012). Heavy metals health risk assessment for population via consumption of food crops and fruits in Owerri, South Eastern, Nigeria. Chemical Central Journal Vol. 6: 77 .

[11] Voegborlo, R. B. and Akagi, H. (2007). Determination of mercury in fish by cold vapour atomic absorption spectrometry using an automatic mercury analyzer. Food Chemistry, 100: 853-858.

[12] Akan, C. J., Audu, L. S., Mohammed, Z. and Ogugbuaja, O. V. (2013). Assessment of heavy metals, $\mathrm{pH}$, organic matter and organic carbon in road side soils in Makurdi metropolis, Benue State, Nigeria. Journal of Environmental Protection, 4: 618-628.

[13] Agbaire, P. O. and Akporhonor, E. E. (2014). Heavy Metal Determination by Sequential Extraction in Agricultural Farmland Soils In Selected Farms In Abraka, Delta State, Nigeria, Journal of Environmental Science, Toxicology and Food Technology, 8: 47-55.

[14] Ojeka, E. O., Adetoyi, I. and Bako, S. S. (2007). Studies on solvent extraction of free hydrogen cyanide from River water. Bulletin of Chemical Society of Ethiopia, 21: 305-313.

[15] Ande, S., Famuyiwa, A. and Iorungwa, M. S. (2015). A preliminary assessment of heavy metals in top soils around WurukumAbbatoir, Makurdi, Benue State, Nigeria. International Journal of Science and Research, 6: 144-147.

[16] Pam, A. A., Sha'Ato, R. and Offem, J. O. (2013). Evaluation of heavy metals in soils around auto-mechanics workshop clusters in Gboko and Makurdi, Central Nigeria. Journal of Environmental Chemistry and Ecotoxicology, 5: 298-306.

[17] Odoh, R., Dauda, M. S., Oko, O. J. and Lawal, U. (2016). Assessment of physico-chemical properties of soil around
Benue Cement companyGboko. Australian Journal of Education and Learning Research, 1: 14-18.

[18] Utsev, T. J., Ajon, T. A. and Ugama, I. T. (2014). Irrigation soil analysis in river Kastina - Ala catchment areas of north central Nigeria. International Journal of Engineering and Technology, 4: 2049-3444.

[19] Iyaka, Y. A. and Kakulu, S. E. (2012). Heavy metal concentrations in top agricultural soils around ceramic and pharmaceutical industrial sites in Niger State, Nigeria. Research Journal of Environmental and Earth Sciences, 4: 171-176.

[20] Amos-Tautua, B. M. W., Onigbinde, A. O. and Ere, D. (2014). Assessment of some heavy metals and physicochemical properties in surface soils of municipal open waste dumpsite in Yenagoa, Nigeria. African Journal of Environmental Science and Technology, 8: 41-47.

[21] Olayinka, O. O., Akande, O. O., Bamgbose, K. and Adetunji, M. T. (2017). Physicochemical characteristics and heavy metal levels in soil samples obtained from selected anthropogenic sites in Abeokuta, Nigeria. Journal of Applied Science and Environmental Management, 21: 883-891.

[22] Odueze, J. C., Nwakonobi, T. U. and Itodo, I. N. (2017). Influence of physic-chemical characteristics of soils on heavy metal contamination in Makurdi, Benue State. Journal of Environmental Science and Food Technology, 11: 84-92.

[23] Ogoloma, J. U., Nkpaa, W. K., Akaninwor, O. J. and Uwakwe, A. A. (2013). Proximate, phytochemical and mineral elements compositions of some edible fruits grown in oil producing community of Rivers State, Nigeria. Journal of Environmental Science, Toxicology and Food Technology, 5: 38-46.

[24] Osarumwense, P. O., Okunrobo, O. L. and UwumarongieIlori, E. G. (2013). Phytochemical analysis of citrus sinensis peel (I) Osbeck. Journal of Applied Science and Environmental Management, 17: 47-50.

[25] Wakili, A., Abdukahi, M. B. and Madara, M. S. (2015). Proximate composition of five commonly used horticultural products in Northen Nigeria. International journal of current microbiology and applied sciences, 4: 924-928.

[26] Uraku, A. J. (2015). Nutritional potential of citrus sinensis and vinifera peels. Journal of Advancement in Medical and Life Science, 3: 1-2.

[27] Chuku, E. C. and Akani, N. P. (2015). Determination of proximate composition and microbial contamination of fresh juice from three citrus species. Journal of Biology and Genetic Research, 1: 1-8.

[28] Udochukwu, U., Igweze, A., Udinyiwe, O. C. and Ijeoma, P. N. (2014). Effect of crude oil pollution on orange (citrus) leaves. International Journal of Current Microbiology and Applied Sciences, 3: 58-64.

[29] Ekpete, O. A., Edor, O. S. and Fubara, E. P. (2013). Proximate and mineral composition of some Nigerian fruits. British Journal of Applied Science and Technology, 3: 1447-1454.

[30] Duressa, T. F. and Leta, S. (2015). Determination of levels of $\mathrm{As}, \mathrm{Cd}, \mathrm{Cr}, \mathrm{Hg}$ and $\mathrm{Pb}$ in soils and some vegetables taken from river Majo water irrigated farmland at Kota village Oromia State, East Ethiopia. International Journal of Sciences, Basic and Applied Research, 21: 352-372. 
[31] Tsuwang, K. D., Ajigo, I. O. and Lar, U. A. (2014). Assessment of lead, mercury and arsenic in soils of Anka area, Northwestern Nigeria. International Journal of Science Environment, 3: 187-197.

[32] Agbaji, E. B., Abechi, S. E. and Emmanuel, S. A. (2015). Assessment of heavy metals level of soil in Kakuriindustria area of Kaduna, Nigeria. Journal of Scientific Research and Reports, 4: 68-78.

[33] Mbe, J. O., Onyekwere, I. N., Ano, A. O., Onweremadu, E. U. and Chukwu, L. I. (2013). Experimental investigation of mercury distribution in polluted soils of Owerri, Southern Nigeria. Greener Journal of Agricultural Sciences, 3: 412-416

[34] World Health Organization and Food and Agriculture Organization (2011). Joint food standards programme codex committee on contaminants in foods, fifth season. The Hague, 21-25 march, Netherlands.

[35] World Health Organization and Food and Agriculture Organization (2010). Summary and Conclusion, joint FAO/WHO expert committee of food additives.(JECFA/73/Sc) 73rd meeting, Geneva. 